\title{
Enterprise Financial Early Warning Model Based on Comprehensive Risk Monitoring
}

\author{
Yansong Cai ${ }^{1,}$, , Siming Chen ${ }^{2, b}$ \\ ${ }^{1}$ School of Economic and Management, Heilongjiang University, P.R.China, 150080 \\ ${ }^{2}$ School of Economic and Management, Heilongjiang University, P.R.China, 150080 \\ acyshrb@163.coml, b1050963536@qq.com
}

\begin{abstract}
Keywords: Comprehensive risk monitoring; Enterprise financial crisis; Early warning model Abstract. According to the shortcoming of current financial early warning model, a early warning model considering the overall risk in the production and operation of enterprises was built. By comprehensive risk analysis, this early warning model can mining the fundamental problems existing in the company. According to the result of early warning, effective measures to avoid the occurrence of financial crisis can be taken.
\end{abstract}

\section{Introduction}

Enterprises financial crisis will directly lead to the closure of enterprises. How to take effective measures to prevent the occurrence of financial crisis is an effective means to safeguard the healthy development of enterprises. The existing financial early warning models focus more on early warning technology and methods but ignores the ultimate goal of corporate financial warning which is to take effective measures to prevent the occurrence of financial crisis. Only the early warning model which can find the fundamental problems existing in the enterprises could help enterprises to develop continuously.

\section{Comprehensive Risk Analysis of Enterprise Financial Crisis}

Enterprise risk refers to the uncertainty that may affect the business objectives. The financial crisis is not an easy course. It is the result of all kinds of risk in the enterprise. As a whole entity, the operation process of the enterprise needs every department to cooperate so as to achieve value increment. At the same time, the risk factors of enterprise operation are in the movement and interact each other. If the interaction between the various risk factors is discord. Sales decline, collection difficulty, lack of funds will occur, which could lead to the financial crises ultimately.

The risk factors leading to the financial crisis are composed of two aspects, which are internal risk factors and external risk factors. Internal risk factors include financing risk, investment risk, income distribution risk and operation risk. External risk factors include political and legal risk, economic risk, technology risk and accounts receivable risk.

The early warning model in this paper will consider all of these two risk resources to evaluate and control the comprehensive risk of enterprise.

\section{Composition of model index system.}

According to the comprehensive risk analysis of enterprise financial crisis, the index system of early financial crisis model is built, which is composed of internal and external index.

Internal Risk Indexes Internal risk indexes are the concrete representation of internal risk factors, which include security surplus cash multiples, quick ratio, asset liability ratio, cash flow debt ratio, return on total assets, return on net assets, sales growth rate, total assets turnover, accounts receivable turnovere, inventory turnover, cost profit margin, capital accumulation rate , quality and level of managers, fnancial management level, staff professional ability, perfect management system. 
External Risk Indexex External indexes are the concrete representation of enternal risk factors, which include policy support and restriction, inflation situation, technical update speed, collection capability.The detail of the index system is shown in Table 1. and Table 2.

Table 1. Internal risk indexes

\begin{tabular}{|c|c|c|c|c|}
\hline Risk factor & Financing Risk & Investment Risk & Operation Risk & $\begin{array}{c}\text { Income Distribution } \\
\text { Risk }\end{array}$ \\
\hline \multirow[t]{4}{*}{$\begin{array}{l}\text { financial } \\
\text { index }\end{array}$} & $\begin{array}{l}\text { security surplus } \\
\text { cash multiples }\end{array}$ & $\begin{array}{l}\text { return on total } \\
\text { assets }\end{array}$ & $\begin{array}{l}\text { total assets } \\
\text { turnover }\end{array}$ & $\begin{array}{l}\text { capital accumulation } \\
\text { rate }\end{array}$ \\
\hline & quick ratio & $\begin{array}{l}\text { return on net } \\
\text { assets }\end{array}$ & $\begin{array}{c}\text { accounts } \\
\text { receivable } \\
\text { turnover }\end{array}$ & \\
\hline & asset liability ratio & sales growth rate & $\begin{array}{l}\text { inventory } \\
\text { turnover }\end{array}$ & \\
\hline & cash flow debt ratio & & $\begin{array}{l}\text { cost profit } \\
\text { margin }\end{array}$ & \\
\hline $\begin{array}{l}\text { non- financial } \\
\text { index }\end{array}$ & $\begin{array}{l}\text { quality and level of } \\
\text { managers } \\
\text { (C1) }\end{array}$ & $\begin{array}{c}\text { fnancial } \\
\text { management } \\
\text { level(C2) }\end{array}$ & $\begin{array}{l}\text { staff professional } \\
\text { ability }(\mathrm{C} 3)\end{array}$ & $\begin{array}{l}\text { perfect management } \\
\text { system } \\
\text { (C4) }\end{array}$ \\
\hline
\end{tabular}

Table 2. enternal risk indexes

\begin{tabular}{c|c|c|c|c}
\hline kinds of index & \multicolumn{4}{|c}{ External risk index } \\
\hline Risk factor & political and legal risk & economic risk & technology risk & $\begin{array}{c}\text { accounts } \\
\text { receivable risk }\end{array}$ \\
\hline $\begin{array}{c}\text { non- financial } \\
\text { index }\end{array}$ & $\begin{array}{c}\text { Environmental protection } \\
\text { policy(A1) }\end{array}$ & $\begin{array}{c}\text { inflation } \\
(\mathrm{A} 2)\end{array}$ & $\begin{array}{c}\text { Technical } \\
\text { update speed(A3) }\end{array}$ & $\begin{array}{c}\text { collection } \\
\text { capability(A4) }\end{array}$ \\
\hline
\end{tabular}

\section{Early Warning Model of Financial Crisis}

For the nomal enterprisese, the early warning model of financial crisis should be practical, easy to operate and low cost. So efficiency coefficient method is used to build the model ${ }^{[1]}$.

The efficacy coefficient method was proposed by Harrington. First ,the single risk index criteria and weights are determined based on efficacy coefficientmethod, which could compute the quantitative score of each single risk index. Then all of the quantitative score of all the risk index will be sumed up to get the finally comprehensive effect coefficient. This method can be applied to not only the financial variables but also the non financial variables, which could solve the difficulty of variable transformation. At the same time, it is easy to operate for any enterprises.

Procesure to Use the Model First, the efficacy coefficient score of financial index will be calculated.Then, non-financial risk index should be quantified. Finally, combined the financial index and non-financial index by specific weight to obtain the enterprise comprehensive effect coefficient. According to "Joint stock commercial bank risk evaluation system", the weight of the financial index is set as $\mathrm{W}_{1}=0.6$, and the non financial index weight is set as $\mathrm{W}_{2}=0.4$. So the comprehensive efficacy coefficient can be calculated according to the Eq.1.

$\mathrm{D}=\mathrm{D}_{1} * 0.6+\mathrm{D}_{2} * 0.4$

$\mathrm{D}_{1}$ for financial index score, $\mathrm{D}_{2}$ for non-financial index score

Calculation of Single Financial Index Score In order to calculate the single financial index score, the risk indexes will be divide into three types, which are very large variable, stable variable and interval variable. Very large variable refers to the variable that higher is better. Stable variable refers to the variable that should stay at a stable level. Interval variable refers to the variable that should be kept in a 
certain range. According to the classification criteria, 12 financial indexes are classified into three categories as in Table 3.

Table 3 Classification of Risk Indexes

\begin{tabular}{c|l}
\hline Risk index type & \multicolumn{1}{c}{ Index name } \\
\hline very large variable & $\begin{array}{l}\text { security surplus cash ratio, inventory turnover rate, the rate of capital } \\
\text { accumulation, return on total assets, accounts receivable turnover, return } \\
\text { on net assets, cost profit margin, total asset turnover, sales growth rate }\end{array}$ \\
\hline stable variable & quick ratio \\
\hline interval variable & cash flow debt ratio, asset liability ratio \\
\hline
\end{tabular}

After the classification of financial indicators, the satisfaction value of each index and the value does not allowed should be determined. According to "enterprise performance evaluation standard value (2015)". For the very large variables, the good value is selected as the satisfaction value, the low value is selected as the not allowed value. For the stable variables, good value is selected as satisfactory value, excellent value and poor value are selected as the upper limit and lower limit. For the interval variables, good value and low value are selected as the upper limit and lower limit of satisifactary value, excellent value and poor value are selected as the upper limit and lower limit of not allowed value.The calculation formulas of these three kinds of variables are shown in Table 4.

Table 4. Calculaion Formula of vabiables

\begin{tabular}{|c|c|c|}
\hline Type of index & Condition & Calculation formula \\
\hline \multirow[t]{2}{*}{$\begin{array}{l}\text { very large } \\
\text { variable }\end{array}$} & $\begin{array}{c}\text { actual value }>=\text { satisfaction } \\
\text { value }\end{array}$ & 100 \\
\hline & $\begin{array}{c}\text { actual value }<\text { satisfaction } \\
\text { value }\end{array}$ & $\begin{array}{c}\text { [ ( actual value - not allowed value ) / ( satisfaction } \\
\text { value - not allowed value ) ]*40+60 }\end{array}$ \\
\hline \multirow[t]{2}{*}{ stable variable } & $\begin{array}{l}\text { actual value }=\text { satisfaction } \\
\text { value }\end{array}$ & $\begin{array}{c}\text { [( not allowed value upper limit - actual value }) /(\text { not } \\
\text { allowed value upper limit - satisfaction } \\
\text { value })]^{* 40+60}\end{array}$ \\
\hline & $\begin{array}{c}\text { actual value }<\text { satisfaction } \\
\text { value }\end{array}$ & $\begin{array}{c}\text { [ ( actual value- not allowed value lower limit }) / \\
(\text { satisfaction value - Not allowed value lower } \\
\text { limit })]^{* 40+60}\end{array}$ \\
\hline \multirow[t]{2}{*}{ interval variable } & $\begin{array}{l}\text { actual value> satisfaction } \\
\text { value upper limit }\end{array}$ & $\begin{array}{c}\text { [1- ( actual value - satisfaction value upper limit }) / \\
(\text { not allowed value upper limit - satisfaction value } \\
\text { upper limit })]^{* 40+60}\end{array}$ \\
\hline & $\begin{array}{c}\text { actual value }<\text { satisfaction } \\
\text { value lower limit }\end{array}$ & $\begin{array}{c}\text { [1- ( satisfaction value lower limit - actual value ) / } \\
\text { ( satisfaction value lower limit - not allowed value } \\
\text { lower limit })]^{* 40+60}\end{array}$ \\
\hline
\end{tabular}

Weight of Individual Financial Index The weight of risk index is used to reflect the influence of each index on comprehensive risk of the enterprise. Considering the influence of different risk factor for different enterprises is variable, Delphy method is used in the early warining model, which could be 
more flexible and convenient. The calculation of comprehensive efficiency coefficient of financial index is shown in Eq.2.

$$
\mathrm{D}_{1}=\sum\left(\mathrm{Fi}^{*} \mathrm{~T}\right)(\mathrm{i}=1,2,3, \ldots, 12)
$$

$F_{i}$ for a single financial index score, $T_{i}$ for a single financial index weights

Efficacy coefficient calculation of non financial index In order to quantify the non-financial index, multilayer fuzzy prediction will be used, whose result is clear and the credibility is high.

The situation of each enterprise non-financial index will be evaluated by experts who are familiar to the field and industry of the enterprise. The number of experts is $\mathrm{n}$. The situation of non-financial index is divided into five types, which are excellent, good, general, poor, very poor. Each expert will evaluate all of the non-financial indexes including internal non-financial indexes and external non-financial indexes. The evaluation results will be gathered. According to the five situation $(j=1,2,3,4,5)$, the protion of each evaluation result number to expert number is calculated. The fuzzy relation matrix of each non-financial index from internal risk can be obtained as $\mathrm{Q}_{1}$. The fuzzy relation matrix of each non-financial index from external risk can be obtained as $\mathrm{Q}_{2}$.

$$
\mathrm{Q}_{1}=\left(\begin{array}{ccccc}
C_{11} & C_{12} & C_{13} & C_{14} & C_{15} \\
C_{21} & C_{22} & C_{23} & C_{24} & C_{25} \\
C_{31} & C_{32} & C_{33} & C_{34} & C_{35} \\
C_{41} & C_{42} & C_{43} & C_{44} & C_{45}
\end{array}\right)
$$

excellet good normal bad very bad

$$
\mathrm{Q}_{2}=\left(\begin{array}{ccccc}
A_{11} & A_{12} & A_{13} & A_{14} & A_{15} \\
A_{21} & A_{22} & A_{23} & A_{24} & A_{25} \\
A_{31} & A_{32} & A_{33} & A_{34} & A_{35} \\
A_{41} & A_{42} & A_{43} & A_{44} & A_{45}
\end{array}\right)
$$

$\mathrm{C}_{\mathrm{ij}}=$ number of experts give evaluation as station $\mathrm{j} /$ number of total experts for the internal risk indexes.

$A_{i j}=$ number of experts give evaluation as station $\mathrm{j} /$ number of total experts for the external risk indexes

i from 1 to $5, \mathrm{j}$ from 1 to 4

Weight of non-financial indexes AHP is used to determine the non-financial index weight in this paper. First of all, the hierarchy of non-financial index is established.Then evey two indexes will be compared according to the imporatance of these non-financial index to the enterprise. Index evaluation hierarchy matrix could be gotten. The characteristic vector of the matrix is the weight matrix of the non financial index

$$
\mathrm{X}_{1}=\left(\begin{array}{lllll}
c_{11} & c_{12} & c_{13} & c_{14} & c_{15} \\
c_{21} & c_{22} & c_{23} & c_{24} & c_{25} \\
c_{31} & c_{32} & c_{33} & c_{34} & c_{35} \\
c_{41} & c_{42} & c_{43} & c_{44} & c_{45}
\end{array}\right) \quad \mathrm{X}_{2}=\left(\begin{array}{lllll}
a_{11} & a_{12} & a_{13} & a_{14} & a_{15} \\
a_{21} & a_{22} & a_{23} & a_{24} & a_{25} \\
a_{31} & a_{32} & a_{33} & a_{34} & a_{35} \\
a_{41} & a_{42} & a_{43} & a_{44} & a_{45}
\end{array}\right)
$$

$\mathrm{c}_{\mathrm{ij}}$ is the important degree evaluation for the internal risk indexes.

$a_{i j}$ is the important degree evaluation for the external risk indexes.

i from 1 to $5, \mathrm{j}$ from 1 to 4

The characteristic vector of these matrix is the weight of internal risk indexes as in $\mathrm{Y}_{1}$ and $\mathrm{Y}_{2}$.

$\mathrm{Y}_{1}=\left\{\mathrm{C}_{1} *, \mathrm{C}_{2} *, \mathrm{C}_{3} *, \mathrm{C}_{4} *\right\}$

$\mathrm{Y}_{2}=\left\{\mathrm{A}_{1} *, \mathrm{~A}_{2}^{*}, \mathrm{~A}_{3}^{*}, \mathrm{~A}_{4}^{*}\right\}$

Evaluation results of internal risk indexes is $A_{1}=Y_{1} * Q_{1}$.

Evaluation results of enternal risk indexes is $A_{2}=Y_{2} * Q_{2}$.

According to the empirical data, the score between 90 and 100 shows the enterprises is excellent. The score beteen 75 and 90 shows the enterprises is good. The score beteen 60 and 75 shows the enterprises 
is normal. The score beteen 40 and 60 shows the enterprises is bad. The score lower than 60 shows the enterprises is very bad. According to the intermediate number of each interval, we get $\mathrm{P}=\{95,82.5,67.5,50,20\}^{[2]}$.

Comprehensive efficacy coefficient of external risk indexU $=A_{1} * P+A_{2} * P=\left\{U_{1}, U_{2}\right\}$

The weight of non financial indicators can also be abtained by AHP as $\mathrm{M}=\left\{\begin{array}{l}m_{1} \\ m_{2}\end{array}\right\}$

Comprehensive efficiency coefficient of non financial index can be calculated byEq.3.

$$
\mathrm{D}_{2}=\left\{\mathrm{U}_{1}, \mathrm{U}_{2}\right\}\left\{\begin{array}{l}
m_{1} \\
m_{2}
\end{array}\right\}
$$

According to the steps above, the enterprise's comprehensive efficacy coefficient score could be calculated according to Eq.1. $\mathrm{D}=\mathrm{D}_{1} * 0.6+\mathrm{D}_{2} * 0.4$

\section{Early Warning Range}

Generally, the final score between 90 and 100 means the enterprise financial risk is almost zero. Its current overwhelm situation is very good. If the final score is between 75 and 90, it means the enterprise financial risk is relative high. If the final score is between 60 and 75, it means the enterprise financial risk is very high. If the final score is lower than 60 , it means the enterprise financial risk is huge.The enterprise is on the brink of bankruptcy. At the same time, the individual score of each risk factor is given, which could guide the manager to take action avoiding the occurrence of bankruptcy.

By analyzing the construction of the final score, we can find the weakness of an enterprise, which is the main reason lower down the total score. So there is more obvious and urgent need for the manager to do something in the corrersponding field. We can not forget the goal of early warning is to avoid the financial crisis. So the early warning model that could give the enterprise the direction to manage the comprehensive risk is more helpful and practical.

\section{Conclusions}

Financial early warning based on comprehensive risk monitoring focus not only the early warning result but also the risk factors that impact the early warning result most seriously. So more targeted action could be taken. The bankrupt chance of the enterprise could be lowered down more effectively.

In this paper, the risk factors and variable indexes are given by detail risk factor analyzing. The early warning indexes are classified into internal risk factors and external risk factors, which are composed of financial and non-financial indexes.

A early model considering the comprehensive risk of enterprises is built using the efficacy coefficient method. The early warning range is given correspondingly.

\section{Acknowledgements}

This work was financially supported by the Heilongjiang Province Philosophy and Social Science Project (12E043) and Department of Education of Heilongjiang Province Planning Project (12532252).

\section{References}

[1] Hongbo Lv: Application of Efficacy Coefficient Method in Enterprise Performance Evaluation. Inner Mongolia Science Technology\&Economy. Vol. 5(2009) , p. 69. in Chinese

[2] Xining Wan, Huang li: The Integrated Fuzzy Forecasting Model of Enterprise Financial Risk. Communication of Finance and Accounting. Vol. 1(2005), p. 29-32 . in Chinese 